UDC 94(57)342.951

DOI https://doi.org/10.32838/2663-5984/2021/3.38

Zou Chengzhang

Beijing Normal University (China)

\title{
THE STALIN PRIZE IN SCIENCE AND ENGINEERING: BETWEEN PROPAGANDA AND PROFESSIONAL RECOGNITION
}

\begin{abstract}
The article deals with the analysis of Stalin Prize in science and engineering as a method of stimulation and recognition of Soviet scientific intelligentsia. A contemporary historiography of the problem has been described. The prerequisites and reasons for the foundation of the award, its evolution in the field of science and technology have been highlighted. It is stressed that the creation of the Stalin Prize provided not only for fixing scientific achievements in the Soviet Union at the state level, but also for establishing clear ideological guidelines for scientists of various fields. The regulatory documents that determined the award of the Stalin Prize have been analyzed. The mechanism of awarding the Stalin Prize has been described, as well as the Prize money for the recipients. The peculiarities of the activity of the Competition Commission of the Stalin Prize in the field of science and technology have been outlined. It is established that J. Stalin personally had the final word in awarding Prizes. It has been noted that an inherent feature of awarding Stalin prizes was its constant adjustment, the lack of reliable documentary evidence. This also applies to the timing of determining the results, and the names of the laureates. Special attention has been paid to the nominees of the Stalin Prize in the field of science and technology and the most famous recipients have been named. It has been noted that some of the nominated works were opportunistic and ideological in its nature. At the same time, it is noted that a number of Stalin Prize winners had previous conflicts with the Soviet government and were imprisoned for political reasons. Special attention has been paid to the recipients of the Stalin Prize, who later received Nobel Prizes. This suggests that the highest Soviet distinction of the Stalinist period was controversial, combining ideological narratives and recognition of significant scientific achievements. The reasons for the liquidation of the Stalin Prize and the creation of the USSR State prize instead have been analyzed.
\end{abstract}

Key words: Stalin Prize, scientific intelligentsia, ideology, stimulation, award.

Problem statement. The Stalin Prize, introduced in 1939, was considered the main distinction in the USSR in the field of science and art until Stalin's death. Its direct connection with the Soviet leader gave this award a special status, because J. Stalin personally participated in the selection of competitive applications. This gave it the role of one of the main ideological guidelines. In fact, the foundation of the award was due to the need to strengthen control over the scientific intelligentsia and was aimed at encouraging the necessary narratives for the Soviet authorities. An objective assessment of the Soviet award system will allow us to understand which factors prevailed when being nominated for the award: ideological or professional?

Analysis of recent research and publications. Despite the fact that the Stalin Prize appears in a number of reference books, scientific monographs and papers, the study of its history, award mechanisms and place in history is just beginning. Scientists have accumulated a considerable amount of work on the history of state awards and their place in the public consciousness. The problem of awarding during the
Stalin era has been studied by M. Dei, A. Diomin, A. Maidebura $[4 ; 5 ; 9]$. Among the general works on the Stalin prizes, we should mention the publications of Russian scientists P. Akhmanayev, I. Venyavkin, and A. Sarsembayev $[1 ; 3 ; 14]$ and the authors of the documentary collection 'Stalin prizes: two sides of one medal' V. Svinyin and K. Oseev [16]. V. Tikhonov's research is devoted to the issue of Stalin awards in the field of historical science [17]. The lack of special research devoted to the analysis of Stalin Prize in all branches of science strengthens the scientific relevance of this paper.

Task statement. The purpose of the article is to research key features of awarding of the Stalin Prize in science and show its ideological role in Soviet society.

Presentation of the main research material. The isolated existence of the Soviet Union in the context of ideological confrontation with Western countries required the authorities to pay more attention to the branches of Science and technology and its representatives. The problem of their loyalty to the Soviet power was relevant for the Soviet 
leadership, especially on the eve of World War II. State encouraging has become an effective method of scientists' stimulation. It was first implemented in 1925 when the Lenin Prize was founded [2, p. 226].

The first prize of an exclusively state-incentive nature was the Stalin Prize, introduced by the Council of People's Commissars of the USSR, as is commonly believed, in commemoration of the 60th anniversary of J. Stalin on December 21, 1939. The number of nominees was supposed to be sixteen people (100 thousand rubles each) for the purpose of annual encouragement of scientists and artists for outstanding works in various fields of science: physical and mathematical, technical, chemical, biological, agricultural, medical, philosophical, economic, historical and philological and Legal Sciences, as well as art-music, painting, sculpture, architecture, theater art and cinematography.

Later, by a decree of February 1, 1940, the Prize was also awarded in the field of literature. Stalin prizes for the best invention were also established (10 first prizes in the amount of 100 thousand rubles, 20 second prizes in the amount of 50 thousand rubles, 30 third prizes in the amount of 25 thousand rubles each); Stalin prizes for outstanding achievements in the field of military science ( 3 first prizes in the amount of 100 thousand rubles, 5 second prizes in the amount of 50 thousand rubles, 10 third awards in the amount of 25 thousand rubles each) and Stalin scholarships for the best students of higher educational institutions [6].

Despite the widespread opinion that the award of the Stalin Prize was timed to coincide with the 60th anniversary of the Soviet leader, the foundation of this award as a method of encouraging and stimulating creative activity was not accidental. The Soviet government intended to summarize the main achievements of the country during the 1930s in the fields of science, technology, literature and art. The main idea was to involve representatives of the scientific and artistic intelligentsia in this process and to assess such important qualities for the authorities as loyalty, correct understanding of party policy, personal loyalty to the leader, etc. This also was required by the country's internal and foreign policy situation.

It should be noted that in the first lists of nominations science, technology and invention were the most important, and achievements in the field of military knowledge and inventions were particularly highlighted. Large funds were provided for such recipients and a larger number of laureates were planned. The same situation was observed in the issue of Stalin's fellows, since the issue of training military personnel was a matter of urgency [16, p. 9].

Special attention should be paid to the mechanism for awarding Stalin prizes, which was regulated by the relevant resolutions of the Council of People's Commissars of the USSR, the Presidium of the USSR Academy of Sciences and the All-Union Committee for Higher School affairs under the Council of people's commissars of the USSR, which were adopted in the first half of 1940. To review the scientific works, a Committee for Stalin Prizes was formed, which included prominent figures of the Bolshevik Party, art and science. It consisted of chairman academician A. Bach, deputy chairmen academician T. Lysenko and S. Kaftanov, and 34 members, including academicians O. Bogomolets, Ye. Varga, V. Komarov, M. Mitin, Ye. Tarle, A. Schmidt, A. Yaroslavsky [6].

After the foundation of the Stalin prize in Literature, two committees were formed - in the field of science and invention and in the field of literature and arts. The committee could allocate sections according to the scientific specialization. Further the committee's decision was sent to the Department of agitation and propaganda, which made its own comments. Then the lists with brief annotations were sent to the members of the Politburo and the Council of People's Commissars (CPC), who submitted their own recommendations. Thus, the award was of a vivid political and propaganda nature. This was especially noticeable in the field of Social Sciences, where political tasks were clearly formulated.

A defining characteristic of the entire mechanism of the establishment and awarding of the Stalin Prizes was its constant adjustment, and not always documented, at least in the form of publications in the press. In particular, in the "Order of awarding Stalin Prizes" approved by the CPC of the USSR and published on 02.04.40 in Pravda, it was determined: "Resolutions of the Council of People's Commissars of the USSR on awarding Stalin Prizes for outstanding works in the field of science, military knowledge, invention, literature and art are published in the central press on December 21" [12]. No other specific date was established by any subsequent resolutions. However, it has never been observed. In fact, the years for which the Prizes were awarded and the years in which the Award Resolutions were published never coincided. Sometimes the gap was several years. In most reference books the year of publication is indicated next to the name of the laureate or the title of the work.

Since I. Stalin personally participated in the award of the Prize, the scientific research that received the 
award immediately became ideological guidelines for other scientists. At the same time, it should be noted that applicants for the award were checked for compliance with current ideological requirements. However, this did not exclude cases of identifying ideological errors in the works of laureates. When selecting nominees, not only the ideological orientation of the research was taken into account, but also the scientific reliability and fundamental nature of the works. Unlike literature, in science, openly propagandistic and insufficiently justified publications were rejected.

The recipients of the award were mostly active specialists. Only for the first awarding it was decided to nominate the works and inventions of the last 10 years. The first award of the Stalin prizes took place on March 16, 1941. The first-degree prize was 100 thousand rubles, the second-degree prize 50 thousand rubles. Totally by the decree of March 13, 1941, 23 first-degree prizes and 20 second-degree prizes were awarded. It should be noted that the awards were presented only in 7 branches of technical and natural sciences - physical and mathematical, technical, chemical, biological, agricultural, medical, geological and mineralogical (since 1942 - geological and geographical). Thus, the total amount of payments amounted to 3.3 million rubles [6].

Among the first laureates were physicist $P$. Kapitsa, electric welder Ye. Paton, geologist V. Obruchev, shipbuilder A. Krylov, founder of chemical physics M. Semenov, mathematician A. Kolmogorov, famous doctors O. Bogomolets and V. Filatov. However, the number of nominated scientists was significantly lower than the number of artists and writers -50 and 162 people, respectively [1, p. 145]. In the field of cinematography alone, 10 first-degree awards and 15 second-degree awards were awarded.

The next award of the Stalin Prize in science for 1941 took place on April 10, 1942 and showed changes in the regulations. First, the list of scientific branches was expanded to 11 compared to last year due to economic, military, historical, philological and philosophical sciences. Secondly, the decree of the Council of People's Commissars of the USSR of January 11, 1942 established that in each branch of science two first-degree and two second-degree prizes are awarded, although when approving the list of prizes, these requirements were not met everywhere. One of the innovations of the resolution was the provision of an advantage in the nomination for the award to works and inventions related to the country's defense. The amount of payments for Stalin prizes was also increased: the amount of the first-degree prize was 200 thousand rubles, and the second-degree price was 100 thousand rubles. In total, by the decree of April 10, 1942, 15 first-degree prizes and 18 second-degree prizes were awarded, and the total amount of payments was 4.8 million rubles $[1$, p. 189; 6].

Further, the names of scientific fields also varied. For example, in the awards for 1942, the nomination «For many years of outstanding works in the field of science and technology» appeared, but in the field of economic sciences the Prize was not awarded. Subsequently, a nomination in the field of legal sciences was added [1, p. 194]. The prizes for 1944 and 1945 were combined and awarded in 1946. For the entire period of the Stalin Prize about 5 thousand people were awarded [6].

The outstanding nominees of the Stalin Prize in science and technology also should be noted. The largest number of awards among scientists was received by aircraft designer S. Ilyushin - seven. His colleagues in the specialty O. Yakovlev, A. Mikoyan and M. Gurevich became six-time laureates. The recognition of aircraft designers is explained by the importance of the industry primarily for the defense capability of the USSR. Three-times winner was agronomist T. Lysenko, who was close to J. Stalin in political position. Among the humanitarians, historians B. Grekov and Ye. Tarle became a threetime winner of the Prize, historians I. Mints and B. Rybakov, and philosopher G. Alexandrov became two-time winners [19]. Among the nominees for the Stalin Prize were future Nobel laureates - physicists P. Cherenkov, I. Tamm, I. Frank (1958), twice winners of the Stalin Prize; L. Landau (1962), A. Sakharov (1975), P. Kapitsa (1978). In fact, A. Sakharov won the Nobel Prize not for the scientific discovery of a hydrogen bomb, but in the field of peacekeeping.

There were also extraordinary cases of awarding the Stalin Prize. So, one of them was V. VoinoYasenetsky (Archbishop Luke of Crimea), the 1946 first stage Stalin Prize recipient for the new surgeon methods of treatment. He combined medical practice with church service. This was the reason for his multiple arrests on charges of counter-revolutionary activities and espionage, his imprisonment and exile for 11 years [6].

A great interest was the process of awarding prizes for 1952, which took place already after the death of I. Stalin in 1953. Then the Stalin Prize acquired an international importance, trying to turn into the main award of the world Communism [17, p. 40]. For the first time, the works of foreign scientists were accepted for the awarding. The main requirement for 
these works was that they should be published in the USSR and in Russian [17, p. 41].

The first nominees were the works of the Czech historian Z. Nejedlý "The history of the Czech people" and Chinese historians Liu Da-Nyan "The history of American aggression in China" and $\mathrm{Hu}$ Sheng "The aggression of imperialist states in China" [17, p. 43]. These scientific works had a vivid ideological character; especially the topic of exposing the imperialist policy of the United States in China was relevant. However, the Department of Science and culture, represented by Chairman A. Rumyantsev, in a note dated July 13,1953, proposed to postpone the award ceremony [17, p. 44]. Another argument was the existence of their own awards in China and Czechoslovakia. In fact, the failure to receive the prize in the field of historical sciences in 1952 was one of the components of the process of de-Stalinization, although it did not mean a complete rejection of Stalin's historical narrative.

Thus, the award ceremony was discontinued in 1954, although official publications about the award were last published in the newspaper Pravda in March 1952 [6; 19]. Despite the fact that on June 30, 1953 the decision of the Presidium of the Council of Ministers of the USSR to award Stalin Prizes for 1952 was made, it was not implemented. One of the reasons was the preparation of a new draft of awards, according to which it was proposed to tighten the requirements for candidates, eliminate conflicts of interest in the selection of laureates, reduce the amount of remuneration and reduce the number of awards. At the same time, it was proposed to create a single Committee for prizes instead of two, which would award the prize not annually, but once every three years. It was also proposed to award scientific and artistic works after a comprehensive public discussion [7, p. 8-9]. The idea was supported by the Soviet authorities N. Khrushchev, M. Suslov, P. Pospelov, who proposed these proposals in a special note. In 1955, the Presidium of the Central Committee of the CPSU instructed to consider the introduction of the Lenin Prize. In the same year, the article about the Stalin Prize disappeared from the Great Soviet Encyclopedia [7, p. 5].

After the 20th Congress of the CPSU, known for denouncing the personality cult and dictatorship of Joseph Stalin, the fate of Stalin's prizes was finally decided. Everyone who was awarded by the prize had to exchange the distinctions for similar badges and diplomas of the State Prize, which became the formal basis later in the reference and scientific literature, the winners of the Stalin Prize, were called laureates of State prizes of the USSR [15, p. 360].

Conclusions. Thus, Stalin prizes in the field of science were awarded exactly 10 times in 13 years-from 1941 to 1954 . They not only captured the importance of scientific work in the public consciousness, but also made the names of a number of scientists wellknown. It is the promotion of success in science that has become one of the main achievements of awards in this field. The prospects of further research are to show the quality of life of the Stalin Prize recipients and its social status in Soviet society.

\section{References:}

1. Ахманаев П. В. Сталинские премии. Москва : Русские Витязи, 2016. 276 с.

2. Борисов Ю.С. Из истории Ленинских премий. История СССР. 1957. № 1. С. 225-232.

3. Венявкин И.В. Краткий путеводитель по Сталинской премии. URL: http://arzamas.academy/ materials/978 (дата обращения: 22.06.2021).

4. Дей М.О. Державні нагороди як найвища форма правового заохочення. Право і безпека. 2005. № 4-5. C. $129-133$.

5. Демин А.Л. Наградная система государства как компонент политической культуры. URL: http://www.dslib.net/soc-filosofia/nagradnaja-sistema-gosudarstva-kak-komponent-politicheskojkultury. html (last accessed: 29.06.2021).

6. Державні премії СРCР. Енииклопедія сучасної Украӥни. URL: http://esu.com.ua/search_articles. php?id=26195 (last accessed: 10.07.2021).

7. Как отменяли Сталинские премии. Документы ЦК КПСС и Совета министров СССР. 1953-1967 / публ. подгот. В.И. Ивкин. Исторический архив. 2013. № 6. С. 3-49.

8. Коритько Д.Г. Нагородне право: стан дослідження проблематики. Держсва і право. 2009. Вип. 44. C. $82-87$.

9. Майдебура А.М. Державні премії в системі державних нагород України. Митна справа. 2007. № 2. C. $39-42$.

10. Об учреждении премий имени В.И. Ленина за научные работы : Постановление СНК CCСР от 23 июня 1925 года. URL: http://www.consultant.ru/cons/cgi/online.cgi?req=doc\&base=ES U\&n=33368\#07088390902195156 (last accessed: 29.06.2021). 
11. Об учреждении премий и стипендий имени Сталина : Постановление Совета Народных Комиссаров Союза ССР от 20 декабря 1939 года № 2078. СП СССР. 1940. № 1. Ст. 6.

12. Порядок присуждения премий имени Сталина. Правда. 1940. № 92.2 апреля.

13. Постановление СНК ССCР от 20 марта 1940 года. Правда. 1940. № 92. 2 апреля. URL: $\mathrm{http}: / /$ www.consultant.ru/cons/cgi/online.cgi? $\mathrm{req}=\mathrm{doc} \& \mathrm{base}=\mathrm{ESU} \& \mathrm{n}=33359 \# 08073056456830663$ (last accessed: 13.07.2021).

14. Сарсембаев А.С. Государственное премирование в отечественном публично-поощрительном механизме: возникновение, становление и развитие до 1991 года. Вестник Уральского финансово-юридического института. 2016. № 3 (5). С. 73-81.

15. Сталинская премия. Сто великих наград / автор-составитель Н.А. Ионина. Москва : Вече, 2005. C. $356-360$.

16. Сталинские премии: Две стороны одной медали : сборник документов и художественно-публицистических материалов / сост. В.В. Свиньин, К.И. Осеев. Новосибирск : Свиньин и сыновья, 2007. 879 с.

17. Тихонов В.В. Неврученная награда: Сталинская премия в области исторических наук за 1952 года. Вестник РГГУ. Серия «Литературоведение. Языкознание. Культурология». 2018. № (4). С. 39-46.

18. Тростин E.M. Страна писателей, страна ученых. URL: https://xn--h1aagokeh.xn--plai/journal/22/ strana-pisatelej-strana-uchenyih-b6.html (last accessed: 11.07.2021).

19. Юркова О.В. Сталінські премії, премії імені Сталіна. Енциклопедія історії Украӥни. URL: http:// www.history.org.ua/?termin=Stalinska_p (last accessed: 12.07.2021).

\section{ЦЗоУ ЧеНЧЖаН. СТАЛІНСЬКА ПРЕМІЯ В ГАЛУЗІ НАУКИ І ТЕХНІКИ: МІЖ ПРОПАГАНДОЮ ТА ПРОФЕСІЙНИМ ВИЗНАННЯМ}

У статті розглянуто Сталінську премію в галузі науки і техніки як механізм заохочення та визнання наукової інтелігенції СРСР. Охарактеризовано сучасну історіографію проблеми. Висвітлено передумови та причини заснування премії, ї̈ еволючію в галузі науки і техніки. Встановлено, що створення премії передбачало не лише фіксаиію на державному рівні наукових досягнень у Радянському Союзі, але й установлення чітких ідеологічних орієнтирів для науковців різних галузей. Проаналізовано нормативні документи, що визначали присудження Сталінської премії. Охарактеризовано механізм вручення Сталінської премії, висвітлено розміри нагород лауреатів. Охарактеризовано особливості роботи конкурсної комісії Сталінської премії в галузі науки і техніки. Встановлено, що вирішальне слово в присудженні премій мав особисто Й. Сталін. Відзначено, щзо притаманною рисою присудження Сталінських премій було його постійне коригування, відсутність чіткого документального підтвердження. Це стосується і термінів визначення результатів, і прізвищ лауреатів. Окрему увагу приділено номінантам Сталінської премії в галузі науки і техніки, охарактеризовано найвідоміших ї здобувачів. Відзначено, що частина номінованих робіт мала кон'юнктурний та ідеологічний характер. Водночас відзначається, щзо низка лауреатів Сталінської премії мала попередні конфлікти з радянською владою та була ув'язнена за політичними мотивами. Окрему увагу приділено здобувачам Сталінської премії, які згодом одержали Нобелівські премії. Це свідчить про те, щзо найвища радянська відзнака періоду сталінізму мала суперечливий характер, поєднуючи ідеологічні наративи та визнання вагомих наукових здобутків. Проаналізовано причини ліквідачії Сталінської премії та створення замість неї Державної премії СРСР.

Ключові слова: Сталінська премія, тоталітарна система, наукова інтелігениія, ідеологія, стимулювання, нагорода. 